\title{
Immigration law enforcement after 9/11 and human rights
}

\author{
Moeckli, Daniel
}

DOI: https://doi.org/10.1017/CBO9780511808371.014

Posted at the Zurich Open Repository and Archive, University of Zurich ZORA URL: https://doi.org/10.5167/uzh-36319

Book Section

Originally published at:

Moeckli, Daniel (2010). Immigration law enforcement after 9/11 and human rights. In: Edwards, Alice; et al. Human security and non-citizens: law, policy and international affairs. Cambridge: Cambridge University Press, 459-494.

DOI: https://doi.org/10.1017/CBO9780511808371.014 
Daniel Moeckli, 'Immigration Law Enforcement after 9/11 and Human Rights', in Alice Edwards and Carla Ferstman (eds), Human Security and Non-Citizens: Law, Policy and International Affairs (Cambridge: Cambridge University Press) (2010) $459-494$ http://www.cambridge.org/us/knowledge/isbn/item2713224/Human\%20Security\%20a nd\%20Non-Citizens/?site_locale=en_US

\title{
CHAPTER 13
}

\section{IMMIGRATION LAW ENFORCEMENT AFTER 9/11 AND HUMAN RIGHTS}

\author{
Daniel Moeckli*
}

\section{INTRODUCTION}

In January 2002, the US Department of Justice announced the so-called Absconder Apprehension Initiative (AAI). ${ }^{1}$ The AAI is a programme designed to locate, arrest, and deport those the US government describes as 'absconders': that is, foreign

${ }^{*}$ This Chapter is a revised version of Chapter 6 of my book, Human Rights and Non-discrimination in the 'War on Terror' (Oxford: Oxford University Press, 2008).

${ }^{1}$ Deputy Attorney General, Memorandum for the INS Commissioner, the FBI Director, the Director of the US Marshals Service and US Attorneys re Guidance for Absconder Apprehension Initiative, 25 Jan. 2002 (Absconder Memo), available at http://news.findlaw.com/hdocs/docs/doj/abscndr012502mem.pdf (last accessed 10 Aug. 2008). For a detailed analysis of the Absconder Apprehension Initiative, see K. Lapp, 'Pressing Public Necessity: The Unconstitutionality of the Absconder Apprehension Initiative' New York University Review of Law and Social Change, 29 (2005), 573. 
nationals who have been ordered to be deported but have failed to leave the United States. $^{2}$ Over 300,000 such persons were thought to be in the United States at that time. ${ }^{3}$ However, these 'absconders' were not to be pursued equally under the AAI. Rather, the US authorities declared that, in order to assist the campaign against terrorism, they would focus on the enforcement of deportation orders against approximately 6,000 'priority absconders' who 'come from countries in which there has been Al Qaeda terrorist presence or activity'. Although the government never explicitly identified these countries, those treated as 'priority absconders' came from a list of states all of which - except for the Philippines - have predominantly Arab and/or Muslim populations. ${ }^{5}$

As I will demonstrate, the AAI is just one in a series of immigration enforcement initiatives adopted in recent years by Western states in the name of preventing terrorism. Typically, these initiatives target particular groups of foreign nationals based on their country of origin or nationality. The purpose of this Chapter is to examine the impacts that these immigration measures have on human rights, in particular the right to non-discrimination. To do this, the Chapter looks at the post9/11 immigration policies of three Western democracies: the United States, the United

\footnotetext{
${ }^{2}$ Absconder Memo, 1.

${ }^{3}$ Ibid.

4 Ibid. See, also, 'DOJ Focusing on Removal of 6,000 Men from Al Qaeda Haven Countries', Interpreter Releases, 79 (2002), 115.

${ }^{5}$ The list of targeted states/territories included: Afghanistan, Algeria, Egypt, Iran, Jordan, Lebanon, Morocco, Pakistan, Palestine Territories, the Philippines, Saudi Arabia, Somalia, Sudan, and Syria. Lapp, 'Pressing Public Necessity', 584.
} 
Kingdom, and Germany, all of them states with relatively large immigrant communities. $^{6}$

In Section II, I show how governments, building on the historic link between the administration of immigration control and national security, have turned immigration law and policy into one of their central tools in the 'war on terror'. The 'securitisation' of migration and refugee policy permeates both the international and national level, manifesting itself in the tightening of immigration laws, the rigorous enforcement of these laws, and the subordination of the immigration machinery to national security agencies. Automatically associating foreign nationals with the terrorist threat, these changes have profound impacts for the human rights of immigrants in Western states.

As Section III demonstrates, not all immigrants have been equally affected by these changes. Just like any other preventive anti-terrorism policy, the use of immigration powers must inevitably rely on profiles of the potential terrorists. With the dominant depiction of the current terrorist threat being linked to wider cultural differences, characteristics such as nationality, national origin, and, at least indirectly, race, ethnicity, and religion have become the key components of such profiles. Thus, as

\footnotetext{
${ }^{6}$ In the United States, 11 per cent of the population are foreign born. US Census Bureau, US Census 2000, 'Profile of General Demographic Characteristics', available at: http://censtats.census.gov/data/US/01000.pdf (last accessed 10 Aug. 2008). In England and Wales, approximately 9 per cent of the population are foreign (non-UK) born: Office for National Statistics, Census, April 2001, available at: http://www.statistics.gov.uk/census/default.asp (last accessed 10 Aug. 2008). In Germany, around 9 per cent of the population are foreign nationals: Statistisches Bundesamt Deutschland, Ausländische Bevölkerung nach Bundesländern, 2006, available at: http://www.statistikportal.de/Statistik-Portal/de_jb01_jahrtab2.asp (last accessed 19 Aug. 2008); P. Stalker, A-Z of Countries of the World (Oxford: Oxford University Press, 2005).
} 
evidenced by numerous policies adopted by the United States, the United Kingdom, and Germany, contemporary immigration law enforcement efforts focus on those immigrants who come from predominantly Arab and/or Muslim states.

Section IV examines whether the differences in treatment based on country of origin or nationality, race, ethnicity, and religion that such selective immigration enforcement efforts involve, are compatible with the right to non-discrimination as guaranteed by international human rights standards and national law. The answer to this question depends, in particular, on the applicable standard of review and on whether singling out immigrants from predominantly Arab and/or Muslim states can be deemed a proportionate means to prevent and investigate terrorist activity.

\section{IMMIGRATION LAW AND POLICY AS AN ANTI-TERRORISM TOOL}

States have often responded to national security threats, including terrorist activities, by trying to keep out of their territory potentially dangerous foreign nationals and by removing, or imposing certain restrictions on, those already in the country. In the wake of September 11, the use of immigration powers for national security purposes has received further impetus.

\section{A. $\quad$ Before September 11}

According to the traditional conception of security, it is the state that is the principal object of security, as well as its guarantor, with other states constituting the main source of security threats. This 'national security' model of security centres on the defence of the state's borders and institutions from external aggression, invariably 
seen as somehow linked to other states. Therefore, governments have always used the control of immigration as a central tool for the protection of national security.

During the so-called Red Scare in the wake of the First World War, for instance, the US authorities relied heavily on immigration laws, in particular the Alien Control Act of 1918, to exclude, detain, and deport perceived left-wing radicals. ${ }^{7}$ Similarly, immigration powers were one of the most important weapons employed in the anticommunist 'witch-hunt' of the McCarthy era of the 1950s. ${ }^{8}$ The United Kingdom reacted to the outbreak of the First World War with the introduction of the Aliens Restriction Act 1914, granting the executive virtually unfettered power to exclude foreign nationals and restrict their freedom of movement, ${ }^{9}$ and with the creation of a machinery of immigration control wedded to the state's security apparatus. ${ }^{10}$ After the war, the 1914 legislation was extended and deployed against, among others, suspected communists. ${ }^{11}$ More recently, the British government used immigration powers for national security purposes by deporting a number of Iraqis and Palestinians at the start of the 1991 Gulf War. ${ }^{12}$ Finally, the internment of 'enemy aliens' has been, in many

\footnotetext{
${ }^{7}$ Migration Policy Institute, America's Challenge: Domestic Security, Civil Liberties, and National Unity after September 11, (2003) 115-120.

${ }^{8}$ S.M. Akram, 'Scheherezade Meets Kafka: Two Dozen Sordid Tales of Ideological Exclusion', Georgetown Immigration Law Journal, 14 (1999) 51, 55-58.

${ }^{9}$ S.S. Juss, Immigration, Nationality and Citizenship (London: Mansell, 1993), 37.

${ }^{10}$ L. Lustgarten and I. Leigh, In from the Cold: National Security and Parliamentary Democracy (Oxford: Oxford University Press, 1994), 167.

${ }^{11}$ K.D. Ewing and C.A. Gearty, The Struggle for Civil Liberties: Political Freedom and the Rule of Law in Britain 1914-1945 (Oxford: Clarendon Press, 2000), 93, 134, 208-209.

${ }^{12}$ See $R$ v. Secretary of State for the Home Department ex parte Cheblak [1991] 2 All ER 319.
} 
states, a regular feature during times of war. ${ }^{13}$ These are just some of the examples demonstrating that, ' $[\mathrm{t}]$ he administration of immigration control has since its inception been inextricably linked with national security. ${ }^{14}$

This close link has also been evident in the specific field of counter-terrorism, even prior to September 11. Despite the rise of the concept of human security in the mid1990s, counter-terrorism policies have remained squarely within a traditional security paradigm. ${ }^{15}$ Immigrants have long been caught up in this paradigm as objects against which states perceived they need protection. Extensive border control powers, for example, were already part of the series of British Prevention of Terrorism (Temporary Provisions) Acts passed between 1974 and $1989,{ }^{16}$ as well as of the Terrorism Act $2000 .{ }^{17}$ In Germany, the authorities reacted to the 1972 terrorist attack at the Munich Olympics by issuing deportation orders against Palestinians considered to be security risks. ${ }^{18}$ Finally, in the United States, the anti-terrorism law adopted after the Oklahoma City bombing of 1995, the Antiterrorism and Effective Death Penalty Act, which is still in force today, mainly consists of measures that are exclusively applicable to immigrants. ${ }^{19}$

\footnotetext{
${ }^{13}$ For the United States, see Enemy Alien Act, 1 Stat 577, 50 USC ss. 21-24. For the United Kingdom, see A.W.B. Simpson, In the Highest Degree Odious: Detention without Trial in Wartime Britain (Oxford: Clarendon Press, 1992).

${ }^{14}$ Lustgarten and Leigh, In from the Cold, 165.

${ }^{15}$ See, further, Ch. 1 by A. Edwards and C. Ferstman in this book.

${ }^{16}$ See, e.g., Prevention of Terrorism (Temporary Provisions) Act 1974, s. 8.

${ }^{17}$ Terrorism Act 2000, s. 53 and Sch. 7.

${ }^{18}$ See BVerfGE 35, 382 - Ausländerausweisung (decision of the Bundesverfassungsgericht (Federal Constitutional Court) quashing the deportation orders because of violations of due process rights and the right to family life).

${ }^{19}$ Anti-Terrorism and Effective Death Penalty Act of 1996, Public Law No 104-132, 110 Stat 1214 (1996) (codified as amended in scattered sections of USC).
} 


\section{B. After September 11}

In the wake of September 11, this link between counter-terrorism measures and immigration control policies has been further reinforced, both at the international and the national levels. The alternative human security approach, popularised in the mid1990s and gaining momentum leading up to September 11, has been pushed aside for a reinvigoration of traditional national security ideals, as terrorism has become a priority.

At the international level, Security Council Resolution 1373, the centrepiece of the UN's response to September 11, requires all member states to adopt a number of immigration measures designed to prevent terrorism. ${ }^{20}$ In particular, states are required to establish effective border controls and to regulate the issuance of identity papers and travel documents, ${ }^{21}$ ensure that those who have participated in, or planned, terrorist acts are not granted refugee status, ${ }^{22}$ and make sure that refugee status is not abused by those involved in terrorism. ${ }^{23}$ In order to implement these obligations, the Counter-Terrorism Committee (CTC), the body monitoring compliance with Resolution 1373, has asked states to introduce legislation covering all these aspects as well as to put in place effective and coordinated executive machinery, including

\footnotetext{
${ }^{20}$ SC Resolution 1373, 28 Sept. 2001, UN Doc. S/RES/1373 (2001).

${ }^{21}$ Ibid., para. 2(g).

${ }^{22}$ Ibid, para. 3(f).

${ }^{23}$ Ibid., para. 3(g).
} 
customs, immigration, and border controls, to prevent the movement of terrorists. ${ }^{24}$ After the London bombings of 7 July 2005, the Security Council reaffirmed these requirements in its Resolution 1624, calling on all states 'to strengthen the security of their international borders, including by combating fraudulent travel documents and, to the extent attainable, by enhancing terrorist screening. ${ }^{, 25}$

In accordance with these requirements, numerous states, including those considered in this Chapter, have considerably tightened their immigration laws in recent years. In the United States, the USA Patriot Act made changes to the immigration law that are designed to improve border controls ${ }^{26}$ and enhance the powers of the immigration authorities. $^{27}$ In particular, the definition of terrorism contained in the Immigration and Nationality Act, and thus the class of non-citizens who can be barred from claiming asylum and removed, has been greatly expanded. ${ }^{28}$ Furthermore, the Attorney General and the immigration authorities have been given wider authority to indefinitely detain immigrants who allegedly endanger national security. ${ }^{29}$ In the United Kingdom, the Immigration, Asylum and Nationality Act 2006 introduced a number of changes designed to provide the government with additional tools to deal

\footnotetext{
${ }^{24}$ Note Verbale of the Chairman of the CTC, 26 Oct. 2001, Ref. SCA/20/01(6).

${ }^{25}$ SC Resolution 1624, 14 Sept. 2005, UN Doc. S/RES/1624 (2005), para. 2.

${ }^{26}$ USA Patriot Act, Public Law No 107-56, ss. 401-405.

${ }^{27}$ Ibid., ss. 411-418.

${ }^{28}$ Ibid., s. 411. For a discussion of these changes, see R. Germain, 'Rushing to Judgment: The Unintended Consequences of the USA Patriot Act for Bona Fide Refugees', Georgetown Immigration Law Journal, 16 (2002), 505.

${ }^{29}$ USA Patriot Act, s. 412; Disposition of Cases of Aliens Arrested Without Warrant, 8 CFR, s. 287.3(d) (2001). See, D. Moeckli, 'The Selective "War on Terror": Executive Detention of Foreign Nationals and the Principle of Non-Discrimination', Brooklyn Journal of International Law , 31 (2006), 495.
} 
with persons considered national security threats. Thus, the act authorises the Home Secretary to deprive persons of their British citizenship (or right of abode) if $s /$ he is 'satisfied that deprivation is conducive to the public good'. ${ }^{30}$ Once stripped of their citizenship, these persons will naturally be subject to deportation powers. Next, the Act provides that in cases where deportation orders are made on national security grounds, an appeal can only be brought after removal. ${ }^{31}$ Finally, the Act makes it easier to deny asylum claims of suspected terrorists by significantly widening the scope of the exclusion clause of the 1951 Convention relating to the Status of Refugees (1951 Refugee Convention), ${ }^{32}$ while at the same time restricting the scope of appeals against rejection of an asylum claim on these grounds. ${ }^{33}$ In Germany, large parts of the Anti-Terrorism Act introduced after September 11 are aimed exclusively at immigrants, increasing border control powers, creating new grounds for exclusion and expulsion, and providing for enhanced data sharing in the field of immigration. ${ }^{34}$ In addition, shortly after the terrorist attacks in Madrid of 11 March 2004, the Zuwanderungsgesetz. (Immigration Act) ${ }^{35}$ was passed, further extending the

\footnotetext{
${ }^{30}$ Immigration, Asylum and Nationality Act 2006, ss. 56-57.

${ }^{31}$ Ibid., s. 7.

${ }^{32}$ Ibid., s. 54.

${ }^{33}$ Ibid., s. 55. The UK Parliamentary Joint Committee on Human Rights has expressed a number of concerns about the national security-related amendments of the Immigration, Asylum and Nationality Act 2006. Joint Committee on Human Rights, Counter-Terrorism Policy and Human Rights: Terrorism Bill and related matters: Third Report of Session 2005-06 (HL 75-I, HC 561-I) paras. 153-185.

${ }^{34}$ Gesetz, zur Bekämpfung des internationalen Terrorismus, 9 Jan. 2002, BGB1 I, 361, Arts. 6, 11-16.
} For a good overview and critical analysis of these changes, see, D. Bender, "Verpolizeilichung" des Ausländerrechts? - Die ausländerrechtlichen Massnahmen des Gesetzgebers nach dem 11. September 2001', Kritische Justiz, 36 (2003), 130.

${ }^{35}$ Gesetz, zur Steuerung und Begrenzung der Zuwanderung und zur Regelung des Aufenthalts und der Integration von Unionsbürgern und Ausländern (Zuwanderungsgesetz), 30 July 2004, BGB1 I, 1950. The Zuwanderungsgesetz introduced two new pieces of legislation, the Aufenthaltsgesetz (Residence Act) and the Freizügigkeitsgesetz/EU (Act on the Freedom of Movement/EU), and made amendments 
government's power to expel foreign citizens on national security grounds. ${ }^{36}$ For example, the authorities are now allowed to expel foreign nationals who 'endorse or promote terrorist acts' or incite hatred against sections of the population. ${ }^{37}$ The Act has also introduced a new summary procedure for the removal of immigrants who allegedly pose a terrorist threat. ${ }^{38}$

The crucial role that immigration policy plays in contemporary efforts against terrorism is also evidenced by the rigorous enforcement of these new, as well as preexisting, immigration powers for anti-terrorism purposes as an alternative (or adjunct) to the instigation of criminal proceedings. The US government has explicitly stated that it regards immigration law enforcement as one of the central planks of its fight against terrorism. ${ }^{39}$ Accordingly, the filing of immigration charges and, conversely, the offering of immigration benefits (such as special visas and relief from removal) as a reward for cooperation are now common tools used in terrorism investigations in the

to different existing laws. See, generally, G. Renner and W. Kanein, Ausländerrecht: Kommentar (München: CH Beck Verlag, $8^{\text {th }}$ edn., 2005).

${ }^{36}$ Aufenthaltsgesetz, Arts 53-55. On the terrorism-related aspects of the Zuwanderungsgesetz, see M. Pelzer, 'Zurück zum Fremden-Polizeirecht? Anti-Terror-Gesetzgebung im Zuwanderungsgesetz', Bürgerrechte \& Polizei, 80 (2005), 21; R. Marx, 'Terrorismusvorbehalte des Zuwanderungsgesetzes', Zeitschrift für Ausländerrecht und Ausländerpolitik, 24 (2004), 275; M. Schmid-Drüner, Der Begriff der öffentlichen Sicherheit und Ordnung im Einwanderungsrecht ausgewählter EU-Mitgliedstaaten (Baden-Baden: Nomos, 2007) 311-320.

${ }^{37}$ Aufenthaltsgesetz, Art. 55(8)(a), (b).

${ }^{38}$ Ibid., Art 58a. See, Renner and Kanein, Ausländerrecht, 520-528; Marx, 'Terrorismusvorbehalte des Zuwanderungsgesetzes', 278-280.

${ }^{39}$ M.B. Sheridan, 'Immigration Law as Anti-Terrorism Tool', Washington Post, 13 June 2005 (quoting statement by M. J. Garcia, Head of Immigration and Customs Enforcement, that immigration laws are 'an incredibly important piece of the terrorism response.') See, also, M.A. Taylor, 'Immigration Enforcement Post-September 11: Safeguarding the Civil Rights of Middle Eastern-American and Immigrant Communities', Georgetown Immigration Law Journal, 17 (2002), 63, 64, 73. 
United States. ${ }^{40}$ Furthermore, immigration law powers have been used in hundreds of cases to detain foreign nationals in connection with terrorism investigations. ${ }^{41}$ The US immigration authorities have also considerably tightened their policies concerning, for example, the closing of deportation hearings to the public, denial of bond, and enforcement of deportation orders in cases allegedly involving national security. ${ }^{42}$

Likewise, after the London bombings, the then British Prime Minster announced a tougher stance on immigration law enforcement: 'The rules of the game have changed. If you come to this country from abroad, don't meddle with extremism, because if you do, or get engaged with it, you are going to go back out again. ${ }^{43}$ Part of this new approach has been the publication of a list of certain, widely defined, 'unacceptable terrorism behaviours' that will be treated as grounds for exclusion and deportation from the United Kingdom. ${ }^{44}$ That the British authorities may readily use their increased immigration powers as a comfortable alternative to the criminal law has been demonstrated in the so-called 'Ricin case': the four Algerians acquitted by the jury from terrorist charges in this case were subsequently detained pending deportation. ${ }^{45}$ Importantly, the British government has made clear its intention to

\footnotetext{
${ }^{40}$ N. V. Demleitner, 'Immigration Threats and Rewards: Effective Law Enforcement Tools in the 'War' on Terrorism?', Emory Law Journal, 51 (2002), 1059.

${ }^{41}$ See, Office of the Inspector General of the US Department of Justice (OIG), The September 11 Detainees: A Review of the Treatment of Aliens Held on Immigration Charges in Connection with the Investigation of the September 11 Attacks (2003).

${ }^{42}$ See, e.g., Taylor, 'Immigration Enforcement Post-September 11', 77-81.

${ }^{43}$ P. Wintour, 'Blair Vows to Root Out Extremism', The Guardian, 6 Aug. 2005.

${ }^{44}$ Home Office, 'Press Release: Tackling Terrorism Behaviours Unacceptable in the UK', 24 Aug. 2005. See, also, the original consultation document: Home Office, 'Exclusion or Deportation from the UK on Non-Conducive Grounds', 5 Aug. 2005.

${ }^{45}$ A. Travis, 'Seven Algerians Held Pending Deportation after Raids', The Guardian, 16 Sept. 2005.
} 
deport foreign terrorist suspects even to states that are notorious for practising torture.

As part of this strategy, it intervened in several cases before the European Court of Human Rights involving deportations, ${ }^{46}$ arguing that the Court should reverse its seminal ruling in Chahal v. United Kingdom. ${ }^{47}$ In the Chahal case, the Court had held that, even if someone is a threat to national security, they may not be removed to a state where they would face a real risk of being subjected to torture or inhuman treatment. ${ }^{48}$ In its judgment of February 2008 in Saadiv. Italy, the Grand Chamber of the European Court of Human Rights rejected the British government's attempt to overturn Chahal. ${ }^{49}$ The second prong of the government's efforts to overcome the restraints of Chahal is the seeking of diplomatic assurances from the states of origin of terrorist suspects that those deported will not be subjected to ill-treatment. The United Kingdom has concluded agreements that systematise the use of such diplomatic assurances with Jordan, ${ }^{50}$ Libya, ${ }^{51}$ Lebanon $^{52}$ and Algeria; ${ }^{53}$ negotiations

\footnotetext{
${ }^{46}$ Ramzy v. the Netherlands, Application No 25424/05; A v. the Netherlands, Application No. 4900/06; Saadi v. Italy, Judgment of 28 Feb. 2008, Application No. 37201/06.

${ }^{47}$ Chahal v. United Kingdom (1997) 23 EHRR 413.

${ }^{48}$ Ibid., paras. 79-80.

${ }^{49}$ See, D. Moeckli, 'Saadi v Italy: The Rules of the Game Have Not Changed', Human Rights Law Review 8 (2008), 534.

${ }^{50}$ Memorandum of Understanding Between the Government of the United Kingdom of Great Britain and Northern Ireland and the Government of the Hashemite Kingdom of Jordan Regulating the Provision of Undertakings in Respect of Specified Persons Prior to Deportation, 10 August 2005. The Special Immigration Appeals Commission (SIAC) held that this memorandum effectively reduced the risk of torture in case of a deportation to Jordan. Omar Othman (aka Abu Qatada) v Secretary of State for the Home Department, SC/15/2005, 26 February 2007. In April 2008, the Court of Appeal upheld the SIAC's decision on this point. Othman (Jordan) v Secretary of State for the Home Department [2008] EWCA Civ 290.

${ }^{51}$ Memorandum of Understanding between the General People's Committee for Foreign Liaison and International Co-operation of the Great Socialist People's Libyan Arab Jamahiriya and the Foreign and Commonwealth Office of the United Kingdom of Great Britain and Northern Ireland Concerning the Provision of Assurances in Respect of Persons Subject to Deportation, 18 October 2005. The SIAC ruled that this memorandum is not a sufficient safeguard against torture. $D D$ and $A S v$ Secretary of State for the Home Department, SC/42/2005 and SC/50/2005, 27 April 2007. This decision was upheld by the Court of Appeal in April 2008. AS and DD (Libya) v Secretary of State for the Home Department [2008] EWCA Civ 289.

${ }^{52}$ Memorandum of Understanding Between the Government of the United Kingdom of Great Britain and Northern Ireland and the Government of the Lebanese Republic Concerning the Provision of Assurances in Respect of Persons Subject to Deportation, 23 December 2005.
} 
to conclude similar agreements with other states are proceeding. ${ }^{54}$ To give further support to this policy, the British government, together with several other states, launched an initiative within the Council of Europe to develop an international instrument that would set minimum standards for the use of diplomatic assurances. ${ }^{55}$ The Council of Europe's Group of Specialists on Human Rights and the Fight against Terrorism, however, rejected this proposal because, among other reasons, it believed that 'such an instrument could be seen as weakening the absolute nature of the prohibition of torture or as a Council of Europe legitimisation of the use of diplomatic assurances. ${ }^{56}$ The United Kingdom has now turned to the European Union in its efforts to receive international endorsement of its diplomatic assurances policy. ${ }^{57}$

In Germany, where enforcement of the immigration laws is entrusted to the Länder (federal states), the authorities have aggressively used their wide powers under the Zuwanderungsgesetz to exclude and deport foreign nationals on national security grounds. In 2005, it was estimated that several hundred, or even up to 2,000 , suspected terrorists would be deported under the new powers. ${ }^{58}$ The Government of Bavaria has established a specific working group, the so-called Arbeitsgruppe BIRGiT $^{59}$ which is tasked with 'making Islamist extremists leave the country. ${ }^{60}$ In

\footnotetext{
${ }^{53}$ Hansard, HL Vol. 696, Col. WA 181 (4 December 2007) (The Minister of State, Foreign and Commonwealth Office (Lord Malloch-Brown)).

${ }^{54}$ Ibid.

${ }^{55}$ Council of Europe, Steering Committee for Human Rights, Group of Specialists on Human Rights and the Fight against Terrorism, Report on first meeting, 16 December 2005, Doc. DH-STER(2005)018.

${ }^{56}$ Council of Europe, Steering Committee for Human Rights, Group of Specialists on Human Rights and the Fight against Terrorism, Report on second meeting, 3 April 2006, Doc. DH-S-TER(2006)005.

${ }^{57}$ See Human Rights Watch, Mind the Gap: Diplomatic Assurances and the Erosion of the Global Ban on Torture (2008) at 10.

${ }^{58}$ See, Pelzer, 'Zurück zum Fremden-Polizeirecht?', 23.

${ }^{59}$ Arbeitsgruppe BIRGiT (Beschleunigte Identifizierung und Rückführung von Gefährdern aus dem Bereich des islamistischen Terrorismus/Extremismus) is part of the Bayerisches Staatsministerium des
} 
that Land alone, the authorities deported forty-five individuals described as 'Islamist extremists and hate preachers' or 'dangerous Islamists' between November 2004 and June 2007; twenty-five others were awaiting deportation. ${ }^{61}$ In Bremen, the government used immigration law to prevent the so-called 'Taliban of Bremen', Murat Kurnaz, a Turkish citizen who had been born and raised in Germany, from returning after his release from Guantánamo Bay- a decision that was later overturned by a Bremen administrative court. ${ }^{62}$

These developments at the legislative and law enforcement levels go hand in hand with significant institutional changes, increasingly subordinating the immigration machinery to the fight against terrorism. Perhaps the clearest example of this is the dissolution of the US Immigration and Naturalization Service, the federal agency once responsible for immigration, and the integration of most of its components into the newly created Department of Homeland Security, whose primary objective is the prevention of terrorist attacks in the United States. ${ }^{63}$ This major administrative reorganisation is emblematic of the fact that immigration policy has now become merely one aspect of the provision of 'homeland security'. Furthermore, since

\footnotetext{
Innern (Bavarian Ministry for the Interior). For a description of the Working Group's activities and procedures, see W. Buggisch and W. Knorz, 'Terrorismusbekämpfung einmal anders: Die AG BIRGiT und das Ausländerrecht als Instrument zur Bekämpfung des islamistischen Terrorismus und Extremismus', Kriminalistik, 4 (2006) 226.

60 See the website of the Working Group, available at: www.stmi.bayern.de/sicherheit/innere/sicherleben/detail/11749/ ('Die Arbeitsgruppe hat die Aufgabe, islamistische Extremisten konsequent zur Ausreise zu bringen.') (last accessed 10 Aug. 2008).

${ }^{61}$ Bayerisches Innenministerium, 'Pressemitteilung Nr 238/07: 70 Ausweisungsbescheide gegen Gefährder, 45 Aufenthaltsbeendigungen', 11 July 2007.

${ }^{62}$ Verwaltungsgericht der Freien Hansestadt Bremen, decision of 30 Nov. 2005, Case No. 4 K 1013/05.

${ }^{63}$ T.W. Donovan, 'The American Immigration System: A Structural Change with a Different Emphasis', International Journal of Refugee Law, 17 (2005), 574.
} 
September 11, the traditional separation between, on the one hand, immigration and, on the other, criminal law enforcement responsibilities has been increasingly blurred through the enhanced involvement of criminal law enforcement officers in immigration enforcement. ${ }^{64}$ It is similarly revealing that in the United Kingdom counter-terrorism and immigration responsibilities were, at least for the first few years after September 11, entrusted to one and the same Minister of State. ${ }^{65}$ In Germany, the federal government established in 2005 a coordination mechanism that is designed to facilitate the transfer of information from the security services to the immigration authorities. ${ }^{66}$ In particular, this body will advise the immigration authorities of cases of foreign nationals who potentially have a 'terrorist background' ${ }^{67}$

Several elements explain the increased reliance on immigration powers as a means to counter terrorism. First, governments may see immigration control as a particularly effective tool because it allows them to bypass the safeguards of the criminal justice system, including access to courts and assistance of a lawyer. The procedural safeguards that apply in the immigration setting are generally less strict; both under the British Immigration, Asylum and Nationality Act 2006 and the summary removal procedure introduced by the German Zuwanderungsgesetz, for example, the scope of

\footnotetext{
${ }^{64}$ Migration Policy Institute, America's Challenge, 80-86.

${ }^{65}$ The post, entitled 'Minister of State for Citizenship, Immigration and Counter-Terrorism', was held, first, by Beverley Hughes and, later, by Des Browne.

${ }^{66}$ The Working Group, called Arbeitsgruppe 'Statusrechtliche Begleitmassnahmen' (AG Status), is based in the Gemeinsames Terrorismusabwehrzentrum (Common Centre for the Defence from Terrorism). See, Bundesministerium des Innern, Praktiker-Erfahrungsaustausch im Rahmen der Evaluierung des Zuwanderungsgesetzes am 30. und 31. März 2006, 66-68; 'Informationsaustausch zwischen Sicherheitsbehörden und BAMF', Asylmagazin 12/2006, available at: www.asyl.net (last accessed 10 Aug. 2008).

${ }^{67}$ Ibid.
} 
judicial review on appeal is severely limited. ${ }^{68}$ Second, and related to this, it will normally be easier for the law enforcement authorities to meet the threshold for the use of immigration powers than to substantiate a terrorism charge. For an expulsion, for example, it must only be demonstrated that the person in question has engaged in some loosely defined behaviour that is taken as indicative that he or she poses a threat to national security. ${ }^{69}$ Third, the broad discretion that the judiciary generally accords governments in the field of immigration law, discussed in Section III.A below, means that there is wide scope for selective enforcement of the respective powers.

While these rationales have already influenced governmental anti-terrorism policies for some time, after September 11 two additional elements have further reinforced the trend towards the use of immigration measures as an anti-terrorism tool. First, the contemporary terrorist threat is generally portrayed as inherently linked to a fundamental civilisational challenge from abroad. ${ }^{70}$ This has led states to rely increasingly on anti-terrorism strategies that are targeted at those who try to enter the country or have entered recently. Such policies are not only designed to incapacitate potential terrorists, but also to deter them from entering, or staying, in the first place. Second, the adoption of measures that are directed against immigrants is a politically convenient way of reacting to national security crises. ${ }^{71}$

\footnotetext{
${ }^{68}$ Immigration, Asylum and Nationality Act 2006, s. 55; Aufenthaltsgesetz, Art. 58a.

${ }^{69}$ For the United Kingdom, see Home Office, Press Release: 'Tackling Terrorism Behaviours Unacceptable in the UK'. For Germany, see Aufenthaltsgesetz, Art 55(8).

${ }^{70}$ See, D. Moeckli, Human Rights and Non-discrimination in the 'War on Terror' (Oxford: Oxford University Press, 2008), 49-54.

${ }^{71}$ See, ibid., 54-55.
} 
To conclude, immigration policy has been radically reshaped in the wake of September 11. Immigration control now not only commonly serves as an additional weapon in the anti-terrorism arsenal but has been almost completely subordinated to counter-terrorism policy. This 'securitisation' of migration and refugee policy has profound impacts on the situation of immigrants to the Western world and their human rights. The use of immigration law as a means to prevent terrorism automatically associates immigration with the terrorist threat and thus contributes to the social construction of immigrants, including refugees and asylum-seekers, as suspected terrorists. This portrayal of immigrants as potential terrorists, in turn, makes restrictions of their fundamental rights appear more acceptable. The UN Special Rapporteur on the Human Rights of Migrants noted in 2003 that '[d]uring the period under review, the Special Rapporteur has observed that the strengthening of security policies and the tendency to consider migration as a matter falling under State security plans pose a threat to the human rights of migrants. ${ }^{72}$ She later reinforced this observation by pointing out that ' $[\mathrm{t}]$ he concept that immigration is a security issue has continued to gain ground since 11 September 2001 and has taken precedence over all other issues, including human rights. The erosion of rights sometimes caused by antiterrorist measures affects immigrants in particular. ${ }^{, 73}$ The myriad immigration restrictions adopted in the name of preventing terrorism impact upon a whole range of migrants' fundamental rights. The expansion of the category of non-citizens who can be barred from claiming asylum on national security grounds, for instance, affects the right to seek asylum; registration for immigration purposes impacts upon the right to

\footnotetext{
${ }^{72}$ Report of the Special Rapporteur on the Human Rights of Migrants, 12 Aug. 2003, UN Doc. A/58/275, para. 6 .

${ }^{73}$ Report of the Special Rapporteur on the Human Rights of Migrants, 22 Sept. 2004, UN Doc. A/59/377, para. 55.
} 
privacy; immigration detention restricts the right to liberty; exclusion based on 'unacceptable terrorism behaviours' may affect the freedom of expression; deportation may touch upon the right to family life and the freedom from torture. Yet even though the human rights of all immigrants have come under increased pressure after September 11, one category of foreign nationals is considered especially suspect and thus made to bear the brunt of the immigration restrictions introduced in the "war on terror'.

\section{SELECTIVITY IN THE ENFORCEMENT}

Just as the tightening of immigration laws and policies as a reaction to national security crises has a long history, so have the selective design and enforcement of such restrictions. After the events of September 11, the trend towards selectivity has intensified.

\section{A. Before September 11}

Among the key factors driving immigration policies of the contemporary state have always been considerations as to the national or ethnic origin, race, and religion of the immigrant population. In the United States, explicit policies of favouring some ethnic groups over others go as far back as the late nineteenth century, when Congress passed a string of selective exclusion laws, directed primarily at Chinese immigrants. ${ }^{74}$ Efforts to influence the ethnic composition of the immigrant population have continued to characterise US immigration law in the twentieth century, ranging from a quota system based upon the national origins of the existing US population

\footnotetext{
${ }^{74}$ J.C. Ting, “'Other Than a Chinaman”: How U.S. Immigration Law Resulted From and Still Reflects a Policy of Excluding and Restricting Asian Immigration', Temple Political and Civil Rights Law Review, 4 (1995), 301.
} 
(decidedly favouring immigrants from Northern European states) to the so-called 'diversity visa program'. ${ }^{75}$ In the United Kingdom, post-Second World War immigration policy was also largely designed to limit non-white immigration, with the Commonwealth Immigrants Acts of 1962 and 1968 and the Immigration Act 1971 as the cornerstones of this policy. ${ }^{76}$ Similarly, German immigration laws have always rested on the axiom that Deutschland ist kein Einwanderungsland ('Germany is not a country of immigration'). ${ }^{77}$ These laws draw distinctions between different categories of immigrants according to their ethnic ties, most clearly reflected in their expansiveness toward ethnic German immigrants from Eastern Europe and their restrictiveness toward non-German immigrants. ${ }^{78}$ Finally, the same kinds of distinctions are manifest in the European Union's common visa scheme, dividing the world into two categories of states: those whose nationals require a visa to enter the Union ('black list') and those whose nationals' entry is considered desirable ('white list'); almost all the states with a predominantly black or Muslim population are on the 'black list'. 79

\footnotetext{
${ }^{75}$ S.H. Legomsky, 'Immigration, Equality and Diversity', Columbia Journal of Transnational Law, 31 (1993), 319.

${ }^{76}$ Juss, Immigration, Nationality and Citizenship, 39-48; I.A. Macdonald and F. Webber (eds.), Immigration Law and Practice in the United Kingdom (London: LexisNexis Butterworths, $6^{\text {th }}$ ed., 2005) 6-9.

${ }^{77}$ C. Joppke, Immigration and the Nation-State: The United States, Germany, and Great Britain (Oxford: Oxford University Press, 1999), 62-65.

${ }^{78}$ D. Kanstroom, 'Wer Sind Wir Wieder? Laws of Asylum, Immigration, and Citizenship in the Struggle for the Soul of the New Germany', Yale Journal of International Law, 18 (1993),155.

${ }^{79}$ R. Cholewinski, 'Borders and Discrimination in the European Union', in M. Anderson and J. Apap (eds.), Police and Justice Co-Operation and the New European Borders (2002) 81; E. Guild, 'The Border Abroad - Visas and Border Controls' in Groenendijk, Guild and Minderhoud (eds.), In Search of Europe's Borders (The Hague: Kluwer, 2003), 87.
} 
In recent years, more subtle forms of race and national origin bias made at the law enforcement level have become increasingly significant, gradually replacing these explicit, de jure classifications. Today, it is often on the basis of immigration laws that are neutral on the surface that certain ethnic groups are singled out. ${ }^{80}$ In the United States, the Supreme Court has, to some extent, sanctioned such selectivity, holding that in the enforcement of the immigration laws - as opposed to criminal law enforcement - ethnic appearance may be lawfully considered as a relevant factor, as long as it is not the only criterion used. ${ }^{81}$ The US immigration authorities therefore regularly rely on ethnicity and national origin when stopping persons in the border $\operatorname{area}^{82}$ or enforcing other immigration powers. ${ }^{83}$ Similarly, the British Race Relations Act includes a clause permitting authorities to discriminate on grounds of nationality or ethnic or national origin (but not race) in carrying out asylum, immigration, and nationality functions if authorised by a minister ${ }^{84}-$ a provision described as 'incompatible with the very principle of non-discrimination' by the UN Committee on the Elimination of Racial Discrimination. ${ }^{85}$

\footnotetext{
${ }^{80}$ See K. R. Johnson, 'Race and Immigration Law and Enforcement: A Response to Is There a Plenary Power Doctrine?', Georgetown Immigration Law Journal, 14 (2000), 289.

${ }^{81}$ United States v. Brignoni-Ponce 422 US 873, 886-87 (1975) (holding that ' $[\mathrm{t}]$ he likelihood that any given person of Mexican ancestry is an alien is high enough to make Mexican appearance a relevant factor' in making a stop in the border area).

82 Johnson, 'Race and Immigration Law and Enforcement', 294.

${ }^{83}$ Ting, "'Other Than a Chinaman”,, 310-312; J.F. Couch, B. King, W.H. Wells and P.M. Williams, Nation of Origin Bias and the Enforcement of Immigration Laws by the Immigration and Naturalization Service, Independent Institute Working Paper No 38, June 2001.

${ }^{84}$ Race Relations Act 1976 (as amended), s 19(D).

${ }^{85}$ UN Committee on the Elimination of Racial Discrimination, Concluding Observations: United Kingdom of Great Britain and Northern Ireland, 10 Dec. 2003, UN Doc. CERD/C/63/CO/11, para. 16.
} 
It is especially during national security crises that states have turned to race, national or ethnic origin, and, in some cases, religion as proxies to define certain groups of immigrants as particularly suspect. During the Second World War, for example, the United States interned Japanese nationals, as well as US citizens of Japanese ancestry, in their tens of thousands, whereas Germans and Italians were spared blanket internment. ${ }^{86}$ More recently, the US authorities introduced special reporting requirements for Iranian students during the Tehran hostage crisis of $1979^{87}$ and photographing and fingerprinting requirements for all entering Iraqi and Kuwaiti nationals during the 1991 Gulf War. ${ }^{88}$

In the specific field of counter-terrorism, similar patterns had already emerged prior to September 11. Hillyard has demonstrated how the far-reaching border control powers of the British anti-terrorism laws passed in the 1970s and 1980s disproportionately affected Irish/Catholic people travelling between Britain and Ireland. ${ }^{89}$ In the United States, the immigration powers of the Antiterrorism and Effective Death Penalty Act of 1996 were almost exclusively deployed against Arabs and Muslims. ${ }^{90}$

\footnotetext{
${ }^{86}$ See, Korematsu v. United States 323 US 214 (1944); Migration Policy Institute, America's Challenge, 122-31.

${ }^{87}$ See, Narenji v. Civiletti 617 F2d 745 (DC Cir, 1979).

${ }^{88}$ Human Rights Watch, Freedom of Expression and the War: Press and Speech Restrictions in the Gulf and F.B.I. Activity in U.S. Raise First Amendment Issues, 28 Jan. 1991.

${ }^{89}$ P. Hillyard, Suspect Community: People's Experience of the Prevention of Terrorism Acts in Britain (London: Pluto Press, 1993), 13-67.

${ }^{90}$ M. J. Whidden, 'Unequal Justice: Arabs in America and United States Antiterrorism Legislation', Fordham Law Review, 69 (2001), 2825; Akram, 'Scheherezade Meets Kafka'.
} 


\section{B. After September 11}

The September 11 attacks have led states to make country of origin or nationality, race, ethnicity, and religion key components of their immigration law enforcement efforts: immigration authorities direct their increased powers listed in Section II above primarily at those who match a profile based on a combination of these elements, often conflating nationality with religion and race by targeting immigrants from states with significant Muslim and Arab populations.

This is most clearly evidenced in the immigration law enforcement strategy of the US authorities, which have adopted a series of policies and practices that single out certain immigrants based on their country of origin or nationality and, at least indirectly (through the choice of the targeted countries), their race, ethnicity, and religion.

First, in November 2001 the US Department of Justice initiated a project to interview 'aliens whose characteristics were similar to those responsible for the attacks.' ${ }^{91}$ Under this so-called Voluntary Interview Program, male immigrants, who were not suspected of any criminal activity, were selected for questioning on the sole basis of fulfilling the following "common-sense criteria" ${ }^{92}$ : they were of a certain age, had entered the United States after January 2000, and originated from countries 'in which intelligence indicated that there was an al Qaeda terrorist presence or activity'. ${ }^{93}$

\footnotetext{
${ }^{91}$ US General Accounting Office (GAO), Homeland Security: Justice Department's Project to Interview Aliens after September 11, 2001, GAO-03-459, Apr. 2003, 1.

${ }^{92}$ V. Dinh, 'Freedom and Security after September 11', Harvard Journal of Law and Public Policy, 25 (2002), 399, 403 (Dinh was serving as Assistant Attorney General when the programme was initiated). ${ }^{93}$ GAO, Homeland Security, 7-8.
} 
Although the authorities did not identify these countries, almost all of the 8,000 men eventually interviewed were Arab and/or Muslim. ${ }^{94}$ In late 2002, in anticipation of the attack against Iraq, the programme was extended to question several thousand Iraqiborn people. $^{95}$

Second, in June 2002 the National Security Entry-Exit Registration System was announced, imposing fingerprinting, photographing, and registration requirements for all males who are citizens of, or were born in, certain designated countries. These requirements apply not only to those from designated countries entering the United States but also to those already present within the United States, through a 'call-in' registration. ${ }^{96}$ By January 2003, the list of states whose nationals are automatically defined as posing an 'elevated national security risk' and are therefore subject to special registration had grown to twenty-five. All of them - except for North Korea are states with predominantly Arab and/or Muslim populations. ${ }^{97}$

Third, the years following September 11 have seen a massive rise in deportation orders for immigrants from predominantly Muslim countries, whilst the

\footnotetext{
${ }^{94}$ Migration Policy Institute, America's Challenge, 41.

95 Ibid., 42.

96 Attorney General John Ashcroft, 'Attorney General Prepared Remarks on the National Security Entry-Exit Registration System', 6 June 2002. For an analysis, see Migration Policy Institute, America's Challenge, 42-45.

${ }^{97}$ The list includes the following states: Afghanistan, Algeria, Bahrain, Bangladesh, Egypt, Eritrea, Indonesia, Iran, Iraq, Jordan, Kuwait, Libya, Lebanon, Morocco, North Korea, Oman, Pakistan, Qatar, Somalia, Saudi Arabia, Sudan, Syria, Tunisia, United Arab Emirates, and Yemen. 68 Fed. Reg. 2363 (16 January 2003); 67 Fed. Reg. 77136 (16 December 2002); 67 Fed. Reg. 70526 (22 November 2002); 67 Fed. Reg. 67766 (6 Nov. 2002); US Immigration and Customs Enforcement, 'Special Registration Groups and Procedures', available at: www.ice.gov/pi/specialregistration/archive.htm (last accessed 10 Aug. 2008).
} 
corresponding figure for other immigrants has remained more or less stable. ${ }^{98}$ For example, although the total number of deportation orders in the United States decreased by about 16 per cent in the first year after September 11, the number of Egyptians who were ordered to be deported increased by 201 per cent and that of Jordanians by 144 per cent. ${ }^{99}$ This national origin bias is also evident in the enforcement of deportation orders: as explained in the Introduction to this Chapter, the AAI, launched in January 2002, prioritised the enforcement of deportation against those 2 per cent of deportable persons who originate from Arab and/or Muslim countries.

Fourth, on the eve of war with Iraq, the Department of Homeland Security announced that, as part of its so-called Operation Liberty Shield, all asylum-seekers 'from nations where al-Qaeda, al-Qaeda sympathizers, and other terrorist groups are known to have operated' would be automatically detained, without the opportunity to have the need for their detention individually assessed. ${ }^{100}$ Although the authorities refused to disclose the list of affected states, the available information indicates that nearly all of them were states with a predominantly Muslim population. ${ }^{101}$

\footnotetext{
${ }^{98}$ For the period from 30 Sept. 2001 to 30 Sept. 2003, a rise of 3 per cent in the total number of deportation orders was recorded; the number of deportation orders against citizens from twenty-four predominantly Muslim states increased by 31 per cent: C. Simpson, F. McRoberts and L. Sly, 'Immigration Crackdown Shatters Muslims' Lives', Chicago Tribune, 16 Nov. 2003.

${ }^{99}$ Ibid.

${ }^{100}$ Department of Homeland Security, 'Press Release: Operation Liberty Shield', 17 Mar. 2003.

${ }^{101}$ Human Rights First, In Liberty's Shadow: U.S. Detention of Asylum Seekers in the Era of Homeland
} Security, 2004, available at: www.humanrightsfirst.org (last accessed 10 Aug. 2008). 
Fifth and finally, the vast majority of those arrested in the post-September 11 preventive detention campaign were immigrants from states with a predominantly Muslim population, primarily Pakistan, Egypt, Jordan, and Yemen. ${ }^{102}$ These hundreds of Muslim men were arrested on minor immigration charges that would not normally warrant arrest, they were detained for exceptionally long periods, and held in conditions of confinement not imposed on similarly situated detainees. ${ }^{103}$

In European countries, including the United Kingdom and Germany, immigration authorities also increasingly rely on the country of origin or nationality, race, ethnicity, and religion to select the targets of their enforcement efforts - although generally in a less explicit manner than the US authorities. In the United Kingdom, the immigration detention powers of the law adopted as a reaction to the September 11 attacks, the Anti-Terrorism, Crime and Security Act (ATCSA) 2001, were used exclusively against Muslim men coming from such countries as Algeria, Morocco, and Egypt. ${ }^{104}$ Likewise, the more recently adopted tougher stance on exclusion and deportation has primarily affected citizens of Middle Eastern and North African states, ${ }^{105}$ in particular Islamic clerics described as 'hate preachers'. 106

In Germany, the immigration authorities in some of the Länder have adopted a policy of requiring immigrants from several specified countries to go through an additional, particularly stringent, national security vetting process before they can be granted a

\footnotetext{
${ }^{102}$ OIG, The September 11 Detainees, 21; Migration Policy Institute, America's Challenge,, App E, 1.

${ }^{103}$ See OIG, The September 11 Detainees.

${ }^{104}$ A. Gillan, 'Who are held, and why?', The Guardian, 17 Dec. 2004.

${ }^{105}$ Amnesty International, Human Rights: A Broken Promise, 23 Feb. 2006, 31-41.

${ }^{106}$ S. Knight, 'Row over New Rules for Deporting Hate Preachers', Times Online, 24 Aug. 2005.
} 
residence permit or renewal thereof. In Bavaria, applicants for a residence permit have to complete a special security evaluation questionnaire if they come from states that are associated with 'an increased probability that potential perpetrators of terrorist acts originate from there. ${ }^{107}$ The Bavarian government has refused to disclose the list of these so-called 'problem states', citing national security reasons. ${ }^{108}$ The Government of Hamburg has instructed its immigration authorities to subject immigrants from certain Arab and African states aged between 16 and 40 to an especially strict vetting procedure, including automatic background checks by the intelligence services for possible connections with terrorist organisations. ${ }^{109}$ The government estimated that about 8,700 foreign nationals would be affected by this special procedure. ${ }^{110}$ In Saxony, 'persons of Arab origin' are required to complete a special questionnaire when applying for a residence permit; this questionnaire is then passed on to the intelligence service for verification. ${ }^{111}$ As far as expulsion is concerned, German authorities have, as explained before, explicitly defined the targets of their aggressive policy of deportation as 'Islamist extremists' or 'dangerous Islamists'. ${ }^{112}$ Among those deported have been a number of so-called 'hate

107 Bayerischer Landtag, Antwort des Staatsministeriums des Innern vom 16.01.2003 auf eine schriftliche Anfrage der Abgeordneten Köhler Elisabeth vom 04.12.2002, Drucksache 14/11340 ('Befragt werden Personen aus Staaten, bei denen mit erhöhter Wahrscheinlichkeit davon ausgegangen werden muss, dass aus ihnen mögliche Täter terroristischer Anschläge einreisen.')

${ }^{108}$ Ibid.

109 'Hamburg verschärft das Aufenthaltsrecht', Die Welt, 18 Feb. 2004.

${ }^{110}$ Ibid.

111 'Sachsen: Fragebögen für Sicherheitsüberprüfung', Asylmagazin 4/2005, available at: www.asyl.net/Magazin/4_2005a.htm (last accessed 10 Aug. 2008).

112 See Section II.B. above. For a critique of the 'dangerous Islamist' classification, see C. von Denkowski, 'Einstufung als (islamistische) Gefährder und (heimliche) Folgeeingriffe', Kriminalistik, 5 (2007), 325. 
preachers', including the high-profile cases of the self-styled 'caliph of Cologne', Metin Kaplan, ${ }^{113}$ and the imam of a Frankfurt mosque, Said Khobaib Sadat. ${ }^{114}$

Various factors explain why the selective enforcement of immigration laws against those coming from countries with predominantly Arab and/or Muslim populations has become one of the central weapons in the anti-terrorism arsenal. Most importantly, the now dominant approach to combating terrorism, of which the use of immigration control measures is a typical manifestation, focuses on the prediction and prevention of risks and thus inevitably relies on profiles of potential terrorists. ${ }^{115}$ Such profiles are constructed in a process that is shaped by the threat perceptions and policy objectives prevalent among the higher levels of government, the intelligence agencies, and the police, which, in turn, both influence and are influenced by the preoccupations of the mass media. ${ }^{116}$ Since the terrorist threat is now generally depicted as being reflective of wider cultural differences, nationality, national or ethnic origin, race, and religion have become the central elements of contemporary terrorist profiles. ${ }^{117}$ Immigrants who match these criteria are therefore treated as particularly suspect. In addition, the focus of immigration law enforcement is also determined by questions of political feasibility. Governments may, for example, be reluctant to direct

113 Oberverwaltungsgericht Münster, decision of 26 May 2004, Case No. 8 A 3852/03.A; Verwaltungsgericht Köln, decision of 12 October 2004, Case No. 12 L 1418/04.

${ }^{114}$ Verwaltungsgericht Frankfurt am Main, decision of 26 Jan. 2006, Case No. 5 E 5870/04.A.

${ }^{115}$ See, Moeckli, Human Rights and Non-discrimination in the 'War on Terror',, 51-55.

${ }^{116}$ See, e.g., P. Schlesinger and H. Tumber, Reporting Crime: The Media Politics of Criminal Justice (Oxford: Oxford University Press,1994); E. S. Herman and N. Chomsky, Manufacturing Consent: The Political Economy of the Mass Media (New York: Pantheon Books,1988); M. Welch, Scapegoats of September 11th: Hate Crimes \& State Crimes in the War on Terror (New Brunswick, NJ: Rutgers University Press, 2006), Ch. 3.

${ }^{117}$ Moeckli, Human Rights and Non-discrimination in the 'War on Terror', 52-55 and 200-206. 
enforcement efforts, such as registration programmes, against citizens of powerful Western states, thereby jeopardising diplomatic relations. The use of terrorist profiles that are based on such highly political considerations is particularly widespread in the field of immigration. This is no coincidence; as the following section demonstrates, the executive has traditionally enjoyed virtually unfettered discretion to selectively enforce its powers in this field.

\section{CONFORMITY WITH THE RIGHT TO NON-DISCRIMINATION}

Selective immigration law enforcement efforts adopted for anti-terrorism purposes such as those described in the previous section treat different categories of foreign nationals differently based on their country of origin or nationality, race, ethnicity, religion, or a combination of these elements. This section assesses the compatibility of such differential treatment with the human right to non-discrimination.

All the major human rights treaties, including the International Covenant on Civil and Political Rights (ICCPR), ${ }^{118}$ which has been ratified by the United States, the United Kingdom, and Germany, and the European Convention for the Protection of Human Rights and Fundamental Freedoms (ECHR), ${ }^{119}$ ratified by the United Kingdom and Germany, prohibit discrimination on all the grounds listed above. Discrimination based on race, colour, descent, or national or ethnic origin is also prohibited by the International Convention on the Elimination of All Forms of Racial Discrimination

\footnotetext{
${ }^{118}$ International Covenant on Civil and Political Rights (ICCPR), 16 Dec. 1966, 999 UNTS 171, Arts. 2,26 .

${ }^{119}$ European Convention for the Protection of Human Rights and Fundamental Freedoms (ECHR), 4
} November 1950, 213 UNTS 222, Art. 14. 
(ICERD), ${ }^{120}$ which has been ratified by all the states at issue. In addition, to the extent that foreign nationals fall within the scope of protection of the 1951 Refugee Convention, the explicit prohibition of discrimination on the grounds of race, religion, or country of origin contained in that Convention applies. ${ }^{121}$ Although the United States has not signed the 1951 Refugee Convention, it has ratified the 1967 Protocol relating to the Status of Refugees, which obliges states to apply the substantive provisions of the 1951 Refugee Convention to all refugees. ${ }^{122}$ The prohibition on the grounds of race and religion is also part of customary international law. ${ }^{123}$ Importantly, non-discrimination is also guaranteed by the national laws of all the states at issue. The United States and Germany have codified this guarantee in their written constitutions. ${ }^{124}$ In the United Kingdom, equality before the law is considered to be a fundamental principle of justice, ${ }^{125}$ and the prohibition of discrimination of the ECHR has been incorporated into domestic law by way of the Human Rights Act 1998.

States are permitted to make certain distinctions between citizens and non-citizens in the context of immigration. ${ }^{126}$ However, this does not mean that those subject to a

${ }^{120}$ International Convention on the Elimination of All Forms of Racial Discrimination (ICERD), 21 December 1965, 660 UNTS 195, in particular Arts 1(1), 2(1)(a), 5.

${ }^{121}$ Convention relating to the Status of Refugees, 28 July 1951, 189 UNTS 150, Art 3.

${ }^{122}$ Protocol relating to the Status of Refugees, 31 January 1967, 606 UNTS 267.

${ }^{123}$ See, for instance, South-West Africa Cases (Second Phase), ICJ Reports (1966), 3, 293 (Tanaka, J, dissenting). Legal Consequences for States of the Continued Presence of South Africa in Namibia (South West Africa) notwithstanding Security Council Resolution 276 (1970), Advisory Opinion, ICJ Reports (1971), 16, 76, 130.

${ }^{124}$ See, US Constitution, Fourteenth and Fifth Amendments; Grundgesetz, Art 3.

${ }^{125}$ See, e.g., Arthur JS Hall v. Simons [2002] 1 AC 615, 688.

${ }^{126}$ See, UN Human Rights Committee, General Comment No 15: The Position of Aliens under the Covenant (1986), para. 5; ICERD, Art 1(2). 
state's immigration powers do not enjoy the protection of the non-discrimination guarantee. Instead, all the relevant non-discrimination standards, including those contained in national laws, apply not only to citizens but also to foreign nationals, irrespective of whether their presence in the host state is lawful or not. ${ }^{127}$ As a consequence, measures relating to the control of immigration and the expulsion of foreign nationals may not involve differential treatment based on grounds such as country of origin or nationality, race, ethnicity, or religion. ${ }^{128}$ For the ICERD, the UN Committee on the Elimination of Racial Discrimination has expressly stated that the prohibition of discrimination on the basis of race, colour, descent, or national or ethnic origin extends to the field of immigration and that states thus have to ensure that immigration and deportation policies do not discriminate among non-citizens based on any of these grounds. ${ }^{129}$ Further, it has made it clear that the prohibition of discrimination of the ICERD also applies to measures taken in the fight against terrorism. $^{130}$

127 See, ibid., paras. 2, 5; UN Committee on the Elimination of Racial Discrimination, General
Recommendation No. 30: Discrimination against Non-Citizens (2004), UN Doc. CERD/C/64/Misc.11/rev.3, paras. 2-4. For the United States, see Plyler v. Doe 457 US 202, 210 (1982) and Zadvydas v. Davis 533 US 678, 693 (2001). For the United Kingdom, see Khawaja v. Secretary of State for the Home Department [1984] AC 74, 111. For Germany, see BVerfGE 30, 409 (412).

${ }^{128}$ See, e.g., UN Human Rights Committee, Concluding Observations: Germany, 4 May 2004, UN Doc. $\mathrm{CCPR} / \mathrm{CO} / 80 / \mathrm{DEU}$, para. 21.

${ }^{129}$ UN Committee on the Elimination of Racial Discrimination, General Recommendation No 30: Discrimination against Non-Citizens, paras 9, 25. See, also, UN Committee on the Elimination of Racial Discrimination, Concluding Observations: Libya, 10 May 2004, UN Doc. CERD/C/64/CO/4, para. 11.

${ }^{130}$ UN Committee on the Elimination of Racial Discrimination, General Recommendation No 30: Discrimination against Non-Citizens, para. 10. 
That the right to non-discrimination is especially prone to violation when states rely on immigration control to counter terrorism has been highlighted by the European Commission against Racism and Intolerance (ECRI). In its Policy Recommendation No 8 on Combating Racism While Fighting Terrorism, it asked states to pay particular attention to ensuring that no discrimination on grounds such as race, colour, religion, nationality, or national or ethnic origin ensues from legislation and regulations - or their implementation - in the areas of border control, expulsion, deportation, and issuing of visas. ${ }^{131}$ Similarly, in its Report on Terrorism and Human Rights, the InterAmerican Commission on Human Rights has stressed that '[m]igrants, asylum seekers and other non-nationals are especially vulnerable to discrimination in emergency situations resulting from terrorist violence' and that states 'must therefore remain vigilant in ensuring that their laws and policies are not developed or applied in a manner that encourages or results in discrimination. ${ }^{132}$ More specifically, the InterAmerican Commission has made it clear that 'to the extent that [immigration control] operations may incorporate criteria, such as national or social origin, that may potentially constitute the basis for discrimination, the content and execution of such operations must be based upon objective and reasonable justifications that further a legitimate purpose, regard being had to the principles which normally prevail in a democratic society, and they must be reasonable and proportionate to the end sought. ${ }^{, 133}$

\footnotetext{
${ }^{131}$ European Commission against Racism and Intolerance (ECRI), General Policy Recommendation No 8, 17 Mar. 2004, Doc. CRI (2004) 26.

${ }^{132}$ Inter-American Commission on Human Rights, Report on Terrorism and Human Rights, 22 Oct. 2002, Doc. OEA/Ser.L/V/II.116, paras. 411-412.

${ }^{133}$ Ibid., para. 412.
} 
As becomes apparent from the Inter-American Commission's comment, the fact that the immigration enforcement measures considered here involve distinctions on the basis of country of origin or nationality, race, ethnicity, and religion does not necessarily mean that they violate the prohibition of discrimination. Government actions inevitably classify persons; the crucial question is whether these classifications are justified or not. According to the jurisprudence of all the relevant human rights bodies and courts, a difference in treatment only violates the right to non-discrimination if persons who are in a comparable position are treated differently and the differential treatment is not supported by objective and reasonable grounds. ${ }^{134}$ But before these two issues are considered, it is necessary to determine the standard that courts should apply to review the immigration law enforcement practices at issue.

\section{A. $\quad$ Standard of review}

National courts have traditionally exercised great deference towards the executive and the legislature as far as policies towards foreign nationals are concerned, particularly with regard to their admission and exclusion. ${ }^{135}$ US courts have generally referred to Congress' plenary power over immigration policies ${ }^{136}$ and British courts to the royal prerogative in the field of immigration to justify this deference. ${ }^{137}$

\footnotetext{
${ }^{134}$ See, e.g., UN Human Rights Committee, General Comment No 18: Non-Discrimination (1989), para. 13; Belgian Linguistics Case (No. 2) (1968) 1 EHRR 252, para. 10.

${ }^{135}$ For the United States, see Chae Chan Ping v. United States 130 US 581, 604-605 (1889); Harisiades v. Shaughnessy 342 US 580, 588-89 (1952); Mathews v. Diaz 426 US 67, 81 (1976). For the United Kingdom, see, e.g., International Transport Roth GmbH v. Secretary of State for the Home Department [2002] EWCA Civ 158, paras. 86-87.

${ }^{136}$ For a summation of the plenary power doctrine, see Kleindienst v. Mandel 408 US 753, 766-69 (1972); Fiallo v. Bell 430 US 787, 792 (1977).

${ }^{137}$ The two leading cases are Musgrove v. Chun Teeon Toy [1891] AC 272 (PC) and Attorney-General for the Dominion of Canada v. Cain [1906] AC 542 (PC). For a critical analysis of the royal
} 
However, this does not mean that courts will automatically exercise self-restraint whenever immigration law issues are concerned. In fact, the case law of the courts of the third state considered in this Chapter, Germany, demonstrates that there is nothing in principle that would prevent the application of the normal principles of judicial review to immigration matters. German courts, including the Bundesverfassungsgericht, have never viewed national sovereignty as requiring an unfettered government power over migration. ${ }^{138}$ In the United States, both commentators $^{139}$ and courts ${ }^{140}$ have in recent years started to advocate a similar position, characterising the plenary power doctrine, which had emerged in a time of expressly racially discriminatory immigration policies (described in Section III above), as increasingly out of step with current realities and understandings of the appropriate role of the courts. A parallel shift in attitude is observable in the United Kingdom. ${ }^{141}$ In the wake of September 11, governments may try to reverse this trend towards greater judicial involvement by arguing that in the face of the current terrorist

prerogative in the field of immigration, see C. Vincenzi, Crown Powers, Subjects and Citizens (London: Pinter,1998), Ch. 4.

${ }^{138}$ For an overview, see G.L. Neuman, 'Immigration and Judicial Review in the Federal Republic of Germany’, New York University Journal of International Law and Politics, 23 (1990), 35.

${ }^{139}$ See, e.g., L. Henkin, 'The Constitution and United States Sovereignty: A Century of Chinese Exclusion and Its Progeny', Harvard Law Review, 100 (1987), 853, 858-863; G.L. Neuman, Strangers to the Constitution: Immigrants, Borders, and Fundamental Law (Princeton University Press, 1996), 118-138; N. Morawetz, 'Rethinking Retroactive Deportation Laws and the Due Process Clause', New York University Law Review, 73 (1998), 97, 122-131.

${ }^{140}$ See, especially the Supreme Court's decisions in INS v. Chadha 462 US 919 (1983); INS v. St. Cyr 533 US 289 (2001); Zadvydas v. Davis 533 US 678 (2001).

${ }^{141}$ See, e.g., S.H. Legomsky, Immigration and the Judiciary: Law and Politics in Britain and America (Oxford: Clarendon Press, 1987), Chs. 4-5; D. Stevens, UK Asylum Law and Policy: Historical and Contemporary Perspectives (London: Thomson/Sweet \& Maxwell, 2004) Ch. 8 (containing a good overview of case law). 
threat they should be allowed to exercise their immigration powers without interference by the courts. In this vein, after the London attacks, the then British Home Secretary explicitly warned judges not to challenge his decision to deport terrorist suspects. ${ }^{142}$ However, the mere fact that a case touches upon national security interests is clearly not a sufficient justification for a deferential standard of review. ${ }^{143}$

In the specific context of selective immigration law enforcement policies and practices that have been adopted for anti-terrorism purposes, three further elements support close judicial scrutiny.

First, even though these initiatives have been adopted in an immigration law context, most of them should properly be considered as criminal law enforcement efforts and thus be subject to the normal principles of judicial review. This is perhaps most obvious with the US Voluntary Interview Program, whose sole purpose appeared to be the gathering of information for criminal investigations into terrorism. ${ }^{144}$ Also a programme such as the AAI has little to do with immigration law enforcement or expedited deportation. In fact, the relevant Department of Justice guidelines make clear that arrests of absconders can be carried out without the presence of any immigration agents, ${ }^{145}$ that absconders should be treated as criminal suspects, ${ }^{146}$ that their names should be entered into a federal criminal database, ${ }^{147}$ and that they should

\footnotetext{
${ }^{142}$ A. Travis, 'Clarke Confronts Judges on Terror Law', The Guardian, 7 Sept. 2005.

${ }^{143}$ See, for instance, D. Feldman, 'Human Rights, Terrorism and Risk: The Roles of Politicians and Judges', Public Law (2006) 364.

${ }^{144}$ GAO, Homeland Security, 3.

${ }^{145}$ Absconder Memo, 4.

${ }^{146}$ Ibid., 2, 4.

${ }^{147}$ Ibid., 2 .
} 
be interviewed about their knowledge of terrorist activity. ${ }^{148}$ Enforcement efforts of a clearly criminal law nature such as these cannot escape close judicial scrutiny simply because they are targeted at immigrants rather than citizens.

Second, even if these initiatives were characterised as immigration law enforcement, strict scrutiny would be called for. This is because where courts have in fact accorded the executive broad discretion in this area, they have largely limited it to the treatment of foreign nationals who have not yet formally entered the country. In other words, governments are given wide latitude to determine the criteria for admission, but once an immigrant has entered and begun to develop social ties, courts tend to apply a more stringent review. ${ }^{149}$ In the present instance, almost all selective enforcement efforts have targeted foreign nationals who had already been residing in the country concerned, in many cases for years or even decades. As explained in Section III.2, even the US initiative that comes closest to admission control, the special registration programme, encompassed not only citizens of specified states entering the United States but also those already present within the United States. The same applies to the German security vetting process, which is also used in the case of applications for the renewal of residence permits.

Third, whereas the case law of national courts and international human rights bodies concerning distinctions based on nationality is inconsistent (only the European Court

\footnotetext{
${ }^{148}$ Ibid., 4. See also Lapp, 'Pressing Public Necessity', 601-603.

${ }^{149}$ For Germany, see, e.g., BVerfGE 76, 1 (46) - Familiennachzug. For the United States, see Landon v. Plasencia 459 US 21, 32 (1982) (holding that 'an alien seeking initial admission to the United States requests a privilege' but that 'once an alien gains admission to our country and begins to develop the ties that go with permanent residence, his constitutional status changes accordingly.')
} 
of Human Rights automatically subjects them to strict scrutiny), ${ }^{150}$ differential treatment on the grounds of race, ethnicity, and religion is uniformly treated as suspect and as entailing strict scrutiny. ${ }^{151}$ This explains why the former US Attorney General, John Ashcroft, claimed that the government's enforcement efforts have been targeted according to nationality: 'We have not identified people based on their ethnic origin. We have identified individuals who are not citizens, but based on the country which issued their passports. ${ }^{, 152}$ Yet a closer look at these initiatives reveals that, in fact, they do not rely on nationality but rather on national origin - and thus on a criterion closely linked to race. This is, in part, already apparent from the official definitions of the target groups. The Voluntary Interview Program, for example, encompassed 'Iraqi-born' people, ${ }^{153}$ while the special registration programme covered not only citizens of, but also those born in, the designated states. ${ }^{154}$ This explicit reliance on national origin is compounded by the selection of the targeted countries of origin, suggesting that this criterion has served as a mere proxy for race and religion: both the immigration enforcement efforts based on specific lists of suspicious countries and those, like the detention initiatives, where such lists have not been drawn up, have been directed almost exclusively at people originating from predominantly Arab and/or Muslim countries. In contrast, citizens of Western states

\footnotetext{
${ }^{150}$ Gaygusuz v. Austria (1996) 23 EHRR 364, para. 42.

${ }^{151}$ For the ECHR, see Timishev v. Russia, Application Nos. 55762/00 and 55974/00, 13 Dec. 2005, para. 58 and Hoffmann v. Austria (1993) 17 EHRR 293, para. 36. For the United States, see Loving v. Virginia 388 US 1, 11 (1967). For the United Kingdom, see Ghaidan v. Godin-Mendoza [2004] UKHL 30, para. 9. For Germany, see BVerfGE 85, 191 (205-206) - Nachtarbeitsverbot.

${ }^{152}$ Department of Justice, 'Attorney General John Ashcroft Provides Total Number of Federal Criminal Charges and INS Detainees', 27 Nov. 2001, available at www.fas.org/irp/news/2001/11/ag112701.html (last accessed 10 Aug. 2008).

${ }^{153}$ Lawyers Committee for Human Rights, Assessing the New Normal: Liberty and Security for the Post-September 11 United States, Sept. 2003, 40.

${ }^{154}$ Migration Policy Institute, America's Challenge, 42-43.
} 
where al Qaeda has demonstrably also been active ${ }^{155}$ have been spared the same treatment. Thus, the nationality criterion has served to single out a group of people whose common defining characteristics are ultimately their race and religion. Distinctions based on these immutable characteristics must inevitably entail strict judicial scrutiny.

\section{B. Comparability}

The immigration law enforcement efforts considered here involve a difference in treatment between, on the one hand, those foreign nationals who originate from predominantly Arab and/or Muslim states and, on the other, those who come from other countries. For a discrimination challenge to succeed, it must be established that these two groups are in a comparable, that is, analogous or relevantly similar, situation, judged in relation to the purpose of the differential treatment. ${ }^{156}$ In the present instance, the selective enforcement of immigration powers serves as a means for the identification and prevention of terrorist activity. In relation to this aim, the two groups are in an analogous situation. First, potential terrorists, including Islamist terrorists, may not only be citizens of Arab or Muslim countries but also of other states. As I will explain in detail in the following section, many of those so far identified as having been involved in Islamist terrorist activities have, in fact, come from Western states. Second, persons belonging to both groups could, theoretically, be targeted equally through immigration law enforcement efforts, since all foreign nationals are subject to the host state's immigration powers. Thus, the two groups are

\footnotetext{
${ }^{155}$ See section C.1. below.

${ }^{156}$ See, e.g., J. Tussman and J. tenBroek, 'The Equal Protection of the Laws', California Law Review, 37 (1949), 341, 346 (for the United States); A v. Secretary of State for the Home Department [2004] UKHL 56, para. 235 (for the United Kingdom).
} 
in a comparable situation and their differential treatment can only be compatible with the right to non-discrimination if it is supported by an objective and reasonable justification.

\section{Objective and reasonable justification}

As I have pointed out in Section IV.A, there are good reasons to argue that the differences in treatment examined here should be characterised as classifications based on race and religion. According to the jurisprudence of both international human rights bodies and national courts, differential treatment based solely on these grounds is automatically suspect and will always be difficult to justify. The British House of Lords, for example, has held that racial stereotyping by immigration officers is impermissible even if it is based on assumptions that may very likely be true. ${ }^{157}$ Consequently, even if it could somehow be established that non-citizens of Arab origin or Muslim denomination are more likely to be involved in terrorism than other foreign nationals, courts might overturn selective immigration enforcement measures that are clearly based on these criteria.

If, on the other hand, the government position is followed, according to which the distinctions at issue are based on the immigrants' country of nationality, the question as to whether the differential treatment may be justified needs to be examined more closely. The inquiry as to the existence of an objective and reasonable justification is

\footnotetext{
${ }^{157} R$ (European Roma Rights Centre) v. Immigration Officer at Prague Airport [2004] UKHL 55, paras. 82 (Baroness Hale), 113 (Lord Carswell).
} 
generally divided into the following two sub-tests. ${ }^{158}$ First, does the difference in treatment pursue a legitimate aim? Second, is there a reasonable relationship of proportionality between the difference in treatment and the legitimate aim sought to be realised? As far as the first requirement is concerned, the aim of the immigration law enforcement efforts at issue is the prevention of terrorist attacks. Undoubtedly, this constitutes a legitimate, even compelling, governmental interest. The decisive question is therefore whether singling out citizens of predominantly Arab and/or Muslim states for enhanced immigration enforcement efforts is a proportionate means of achieving this aim. It is helpful to examine the question of proportionality in two steps, relating, first, to the suitability and effectiveness of the selective enforcement efforts at issue and, second, to their possible negative effects.

\section{Suitability and effectiveness}

It is doubtful in two respects that the kind of immigration law enforcement measures described in this Chapter are a suitable and effective, and thus proportionate, means to detect and prevent terrorist activity. First, there are inherent limits to the usefulness of a strategy that relies on immigration law powers to counter terrorism. Second, a person's country of origin or nationality is not an appropriate criterion to target the enforcement of these powers for anti-terrorism purposes.

The first problem is due to the fact that immigration control systems are not able - or even intended - to identify international terrorists. The restrictive measures provided by these systems can only be deployed effectively as far as intelligence and criminal

\footnotetext{
${ }^{158}$ See, e.g., UN Human Rights Committee, General Comment No 18: Non-Discrimination (1989), para. 13; Belgian Linguistics Case (No. 2) (1968) 1 EHRR 252, para. 10.
} 
law agencies provide information as to potential targets. ${ }^{159}$ Thus, the general strengthening and strict enforcement of immigration laws are, in themselves, unlikely to disrupt the activities of foreign terrorists - unless, perhaps, a state goes as far as completely closing its borders and expelling all foreign nationals. As a senior Western intelligence official put it, 'tightening immigration control doesn't help you that much until the intelligence side gives you a name, and then it helps you track them. ${ }^{160}$ This statement is reinforced by the findings of the 9/11 Commission, which concluded that the attacks of that date were made possible mainly by the intelligence agencies' failure to properly assess and share information. ${ }^{161}$ Furthermore, many immigration law enforcement efforts, including the AAI and the use of immigration charges to hold potential terrorists, are only directed at those who are in violation of the immigration law. Yet foreign terrorists are not necessarily illegally in the country they are planning to attack. In fact, a study of 373 Islamist terrorists arrested or killed in Europe and the United States between 1993 and 2004 showed that only six per cent of them had entered the respective host country illegally. ${ }^{162}$ Finally, even as far as immigration control measures do affect terrorists, their effectiveness is very limited: exclusion and deportation merely relocate the structural components of terrorism rather than to seriously disturb or eliminate them. ${ }^{163}$ The British Newton Committee, a committee of Privy Counsellors set up to review the operation of the ATCSA, therefore concluded:

\footnotetext{
${ }^{159}$ Migration Policy Institute, America 's Challenge, 31.

${ }^{160}$ Ibid., 17.

${ }^{161}$ National Commission on Terrorist Attacks Upon the United States, The 9/11 Commission Report: Final Report of the National Commission on Terrorist Attacks Upon the United States (2004), Ch. 13.

${ }^{162}$ R. S. Leiken and S. Brooke, 'The Quantitative Analysis of Terrorism and Immigration: An Initial Exploration', Terrorism and Political Violence, 18 (2006), 503, 510.

${ }^{163}$ Demleitner, 'Immigration Threats and Rewards', 1069.
} 
Seeking to deport terrorist suspects does not seem to us to be a satisfactory response, given the risk of exporting terrorism ... While deporting such people might free up British police, intelligence, security and prison service resources, it would not necessarily reduce the threat to British interests abroad, or make the world a safer place more generally. Indeed, there is a risk that the suspects might even return without the authorities being aware of it. ${ }^{164}$

In summary, while the use of immigration powers may be, for the reasons explained in Section II above, an attractive and convenient option for governments to react to terrorist threats, it is also a largely ineffective one.

The second concern, relating to the suitability and effectiveness of the selective enforcement approach, derives from the fact that a lack of reliable and specific information on terrorists cannot be compensated for by the use of stereotypes. Such a broad criterion as a person's country of origin or nationality is not narrowly tailored enough to target effectively immigration law enforcement efforts for anti-terrorism purposes. To subject all nationals of certain states to enhanced scrutiny and particularly harsh treatment clearly runs counter to the principle of proportionality. This is all the more true given that there is no evidence for a possible connection between a person's nationality and his or her likelihood to be involved in terrorism. The mere fact that someone comes from a country where there has been al Qaeda

\footnotetext{
${ }^{164}$ Privy Counsellor Review Committee, Anti-terrorism, Crime and Security Act 2001 Review: Report (HC 100, 2003), para. 195.
} 
presence or activity can hardly be regarded as a compelling indication of dangerousness. After all, as highlighted by Legomsky, immigrants are not representatives of the countries they leave behind: 'Countries don't immigrate. People do. ${ }^{165}$ Thus, reliance on a stereotypical, overbroad criterion instead of specific information relating to individuals makes the selective enforcement efforts at issue unsuitable and disproportionate means of countering terrorism. It is for this reason, for example, that the UN High Commissioner for Refugees has expressed concern about the mandatory detention of asylum seekers based on nationality under the US Operation Liberty Shield: 'Detention of asylum seekers ... should be based on an individualized assessment of the security risk the person poses. Blanket mandatory detention based on nationality varies from accepted international human rights norms and standards. ${ }^{166}$

It is, in any event, difficult to discern the logic behind the selection of the states whose nationals have been targeted by the measures under consideration. As explained in Section III.2, the immigration law enforcement efforts of all three states considered have concentrated almost exclusively on (primarily male) citizens of around twenty to twenty-five Arab and/or Muslim states where there has, allegedly, been al Qaeda presence or activity. Yet, at the same time, a list compiled by the US Department of State of 'Countries Where Al Qaeda Has Operated' comprised forty-five states, including numerous Western countries such as France, Germany, Switzerland, the United Kingdom, and the United States, while excluding some of the Middle Eastern

\footnotetext{
${ }^{165}$ Legomsky, 'Immigration, Equality and Diversity', 334.

${ }^{166}$ UNHCR, 'Press Release: UNHCR appeals for protection of asylum seekers in the United States', 20 Mar. 2003.
} 
states singled out by the initiatives at issue, such as Syria. ${ }^{167}$ Furthermore, the study of Islamist terrorists referred to above showed that less than half of these terrorists were born in the Middle East and that 41 per cent of them were nationals of Western states; there were more Britons than Yemenis, Sudanese, or Libyans and twice as many French nationals as Saudis. ${ }^{168}$ Therefore, if a link between the country of nationality and terrorist involvement was to be made, then nationals of Western states would have to be targeted as well. In this sense, the selective immigration law enforcement efforts at issue are not only over-inclusive in that they rely on the broad, disproportionate criterion of country of nationality: they are also under-inclusive in that they fail to include within their scope a large portion of potential terrorists. To conclude, the perception that terrorism is part of a wider cultural conflict, as well as considerations of political feasibility, have led states to use a proxy for terrorist threats that is overbroad, under-inclusive, and inappropriate.

It is therefore not surprising that there is no evidence that would suggest that these selective enforcement measures have been effective. For example, not one of the tens of thousands of immigrants registered under the US special registration programme has been charged with terrorist activity. ${ }^{169}$ Similarly, the mass of information resulting from the Voluntary Interview Program has not even been properly analysed, and the

167 The list was posted on 10 Nov. 2001 on the State Department website, at http://usinfo.state.gov/products/pubs/terrornet/12.htm, but later removed. An exact capture is available at www.fred.net/tds/Osama_bin_Laden_and_al_Qaeda_2001nov10/12.htm (last accessed 19 Aug. 2008).

${ }^{168}$ Leiken and Brooke, 'The Quantitative Analysis of Terrorism and Immigration', 508. See, also, R. Leiken and S. Brooke, 'Al Qaeda's Second Front: Europe', International Herald Tribune, 15 July 2005.

${ }^{169}$ Lawyers Committee for Human Rights, Assessing the New Normal, 39. 
project has apparently not produced any investigative leads. ${ }^{170}$ Of the few individuals who were taken into custody based on the interviews, most were charged with minor immigration violations; none of these cases seem to have any connection to terrorism. ${ }^{171}$ This lack of effectiveness reinforces the conclusion that there is no compelling link between the traits relied on for these law enforcement initiatives and terrorist activity.

\section{Negative effects}

A proportionality assessment of the sort of immigration law enforcement practices described in this Chapter must also take account of their wider implications. The available evidence suggests that such selective enforcement methods may have serious negative impacts on community relations and thus ultimately prove to be an impediment to anti-terrorism efforts.

These counter-productive effects are, again, best documented for the selective enforcement programmes implemented by the US authorities. A series of interviews carried out by an independent research institute with representatives of Arab and Muslim communities in the United States demonstrates that these groups feel targeted and isolated by the government's policies described above. ${ }^{172}$ One interviewee stated that the cumulative effect of all these measures for the Muslim community had been 'isolating instead of integrating.' ${ }^{173}$ The special registration programme has even prompted an exodus of some immigrant groups from the United States; in one

\footnotetext{
${ }^{170} \mathrm{GAO}$, Homeland Security, $6,16$.

${ }^{171}$ Ibid., 6.

${ }^{172}$ Migration Policy Institute, America's Challenge, 87-90.

${ }^{173}$ Ibid., 90.
} 
Brooklyn neighbourhood alone, an estimated 15,000 Pakistanis left. ${ }^{174}$ This also shows that selective immigration law enforcement efforts impact upon a much wider group than only those directly affected by them: by singling out a particular category of foreign nationals, they intimidate, alienate, and stigmatise all those who share the relevant characteristics.

This sense of intimidation and alienation within certain immigrant communities has important consequences in terms of their readiness to cooperate with law enforcement agencies - cooperative law enforcement depends upon mutual trust. ${ }^{175}$ Given that the collection of intelligence in investigations into international terrorist networks also depends on good sources in immigrant communities, ${ }^{176}$ this may be extremely costly in the longer term. As a former CIA counter-terrorism official has pointed out: '[W]hen we alienate the communities, particularly immigrant communities, we undermine the very basis of our intelligence collection abilities because we need to have the trust and cooperation of people in those communities. ${ }^{177}$ It is precisely for this reason that in the United States several local police departments refused to participate in the Voluntary Interview Program; such selective enforcement efforts, they argued, could jeopardise the trust with immigrant communities that they had built up over the years. ${ }^{178}$

\footnotetext{
${ }^{174}$ Lawyers Committee for Human Rights, Assessing the New Normal, 39.

${ }^{175}$ E.g., D. Harris, 'The Stories, the Statistics, and the Law: Why "Driving While Black" Matters', Minnesota Law Review, 84 (1999), 265, 307-309.

${ }^{176}$ See, Migration Policy Institute, America's Challenge, 17.

${ }^{177}$ Lawyers Committee for Human Rights, Assessing the New Normal, 38.

${ }^{178}$ F. Butterfield, 'A Nation Challenged: The Interviews; Police Are Split On Questioning of Mideast Men', New York Times, 22 Nov. 2001.
} 
Even more fundamentally, measures singling out immigrants who originate from Middle Eastern and Muslim states for particularly harsh treatment contribute to the construction of the concept of a 'clash of civilizations' ${ }^{179}$ Through their choice of the targeted countries of nationality, they reinforce the notion that terrorism is but a manifestation of a broader, cultural and religious, conflict. It is exactly this notion that, in turn, is one of the most powerful arguments used by Islamist terrorist organisations themselves to recruit new members, including second- and thirdgeneration immigrants in Western states. ${ }^{180}$

\section{Result}

Immigration law enforcement efforts focusing on citizens of predominantly Arab and/or Muslim states treat two groups differently who are in a comparable situation: immigration law enforcement agencies could equally target foreign nationals originating from other states for anti-terrorism purposes. Because these measures serve criminal (rather than immigration) law enforcement purposes and because they will often affect immigrants who reside in the host country, courts should employ strict scrutiny to review discrimination challenges to them. Thus, the differential treatment they involve could only be justified if it is supported by compelling reasons.

Yet in a terrorism context there are no objective and reasonable grounds for making distinctions between different categories of foreign nationals according to their country of origin or nationality. Even though singling out people for special treatment

\footnotetext{
${ }^{179}$ See, S. P. Huntington, ‘The Clash of Civilizations?', Foreign Affairs, 73 (1993), 22.

${ }^{180}$ See, J. Burke, Al-Qaeda: Casting a Shadow of Terror (New York: Tauris \& Co. Ltd, 2003), 238240.
} 
based on their nationality is always problematic from a discrimination perspective, it may be understandable that a state considers a non-citizen's country of nationality a relevant factor of a risk assessment if it is involved in an armed conflict with that country. Thus, a US court held during the Tehran hostage crisis that there was a 'rational basis' for a regulation requiring Iranian students to report to the immigration authorities. ${ }^{181}$ For the purpose of the fight against terrorism, however, a person's nationality is irrelevant. The purported 'war on terror' is not an inter-state conflict, and policies that aim at excluding or removing all nationals of certain states are grounded in a traditional conception of security that is unhelpful in the context of contemporary international terrorism. This is a conception that emphasises territory instead of people and thus implies that terrorism can somehow be linked to certain states, that all nationals of these states can be treated as unitary actors and that the threat can be addressed through the protection of the borders. Yet, in reality, immigration law enforcement can only contribute to the prevention of terrorism if it is based on a detailed, individualised appreciation of the threat and concrete information. Enforcement efforts that rely on broad stereotypes such as nationality or national origin, in contrast, are unsuitable and ineffective, and thus disproportionate, means to counter terrorism. As a consequence, they violate the right to nondiscrimination as guaranteed by international human rights standards and national law.

\section{CONCLUSION}

With the portrayal of contemporary terrorism as a war-like phenomenon rooted in fundamental cultural differences and, thus, as primarily emanating from abroad, the

${ }^{181}$ Narenji v. Civiletti 617 F2d 745, 748 (DC Cir, 1979). 
reinforcement of the borders and the removal of potential security risks from the country may seem a logical response. It is a way of reacting to national security crises that has a long tradition. It is, at the same time, a way of reacting that is characteristic of the risk management approach that underlies today's crime-fighting strategies in general. ${ }^{182}$ Especially the use of deportation powers to counter terrorism may be seen as the archetypical manifestation of this approach: relocating rather than resolving potential threats, deportation is primarily aimed at producing a short-term sense of security. Yet the impression of security created by the adoption of immigration restrictions is - even in the short term - a false one. With the huge numbers of people crossing borders every day, ${ }^{183}$ it is - at least for a society that wants to stay relatively open - a close to impossible task to filter out potential terrorists. As is widely acknowledged, even vastly expanded immigration powers and border controls could not have prevented the September 11 hijackers from entering the United States. ${ }^{184}$ In the longer term, and certainly from a global perspective, risk management strategies such as deportation may actually be counterproductive, since potential terrorists may be better able to operate from the states to which they are deported. ${ }^{185}$

\footnotetext{
${ }^{182}$ See, e.g., M. Feeley and J. Simon, 'Actuarial Justice: The Emerging New Criminal Law', in D. Nelken (ed.) The Futures of Criminology (London: Sage,1994), 173; R. V. Ericson and K. D. Haggerty, Policing the Risk Society (Oxford: Clarendon Press,1997); D. Garland, The Culture of Control: Crime and Social Order in Contemporary Society (Oxford: Oxford University Press, 2001), especially Chs. 5 and 7.

${ }^{183}$ For example, each year more than 500 million people enter the United States: Office of Homeland Security, The National Strategy for Homeland Security, July 2002, available at: www.whitehouse.gov/homeland/book/nat_strat_hls.pdf (last accessed 10 Aug. 2008), p. 21.

${ }^{184}$ E.g., Migration Policy Institute, America's Challenge, 8-11.

${ }^{185}$ Demleitner, 'Immigration Threats and Rewards', 1093.
} 
The use of immigration laws as an anti-terrorism tool is also typical of the risk management approach in another respect: since prediction and prevention of risks is at the heart of this approach, it relies on profiles of the potential targets. As the figure of the contemporary terrorist lacks particular psychological or behavioural characteristics, these profiles are inevitably vague. ${ }^{186}$ Thus, individual-focused law enforcement practices, based on specific information, are replaced with the targeting of whole groups, based on broad characteristics. In the immigration control context, it is particularly the country of origin or nationality that has come to be seen as an indicator of a propensity to terrorism. Through the exclusion and removal of all those accordingly defined as posing a heightened security risk, states try to shift the responsibility of dealing with these risks back to the state that is blamed for their production: the 'home' state. Rather than addressing the terrorist threat in a comprehensive, coherent, and principled manner, immigration enforcement practices that follow this logic are mainly designed to play to domestic political concerns. As a consequence, they involve differences in treatment that are not based on objective and reasonable grounds and are therefore incompatible with the right to nondiscrimination.

${ }^{186}$ See, Moeckli, Human Rights and Non-discrimination in the 'War on Terror', 52 and 201. 